\title{
QUANTIFIED ANALYSES OF AGGRESSION PATTERN IN A CAPTIVE POPULATION OF MUSK DEER (MOSCHUS SIFANICUS)*
}

\author{
Xiuxiang Meng ${ }^{1}$, Andrew Sih ${ }^{2}$, Haitao $\mathrm{Li}^{3}$, Nicholas Cody ${ }^{1}$ \\ ${ }^{1}$ College of Life and Environmental Sciences, Minzu University of China, 27 Zhongguancun Nandajie, \\ Beijing 100081, China \\ ${ }^{2}$ Department of Environmental Science and Policy, University of California at Davis, Davis, \\ CA 95616, USA \\ ${ }^{3}$ School of Animal Science, Xichang College, Xichang 615013, China \\ Corresponding author: mengxiuxiang2006@hotmail.com
}

\begin{abstract}
Alpine musk deer (Moschus sifanicus) are endangered as a result of habitat degradation and loss and centuries of widespread poaching. Consequently, musk deer farming was introduced as a measure to not only protect musk deer but also to provide a means for sustainable musk supply. An increased understanding of the social structure of captive populations is essential for both successful farming and improved welfare of individuals. This study recorded agonistic interactions between captive individuals at Xinglongshan Musk Deer Farm (XMDF), northwest China. The relationship between aggressive interactions and the individual's age and gender and opponent health was analysed. From our observations we found that stable social hierarchies developed within both captive male and gender-mixed musk deer groups. There was no significant correlation found between only age of individual and their status in the social hierarchy, and it was thus concluded, as social rank was not determined singularly by age, that a combination of other factors, such as experience and origin of the individual, better explain rank orders. Three forms of aggressive behaviour were expressed between males, in which threatening $(56.38 \% \pm 7.28 \%)$ was significantly more frequent than attacking $(17.86 \% \pm 5.94 \%)$ and displacing behaviours $(25.78 \% \pm 3.66 \%)$. There was no attacking behaviour observed in interactions initiated by males towards females, however displacing $(\mathbf{7 0 . 8 5 \%} \pm \mathbf{4 . 1 5 \% )}$ ) was more common than threatening $(29.15 \% \pm 4.15 \%)$. Conflict-initiating male deer demonstrated more attacking and threatening behaviour towards male opponents than to female ones, however the differences were statistically insignificant. These results can be implemented into musk deer farming management practices through 1) rotating individuals within an enclosure on a frequent basis; 2) removing males from female enclosures after successful mating and 3) enclosing males in single sex enclosures. Furthermore, in order to improve musk deer farming and captive musk deer welfare, management systems should be kept relatively consistent in order to assist in establishing the stable social hierarchy patterns in captive populations.
\end{abstract}

Key words: Alpine musk deer (Moschus sifanicus), fight techniques, social rank, influencing variables, welfare

*This research was supported by Nature Science Foundation of China $(31170364,30970374)$, the "985 Project" of Minzu University of China (MUC98504-14, MUC98507-08) and Program for New Century Excellent Talents in University (NCET-08-0596). 
Musk deer (Moschus spp.) are small solitary forest ruminants well known for the musk secreted by adult males, which is a valuable medicinal resource used in traditional Asian medicine (Parry-Jones and Wu, 2001; Meng et al., 2006; Shrestha, 1998). As a result of habitat degradation and loss and a legacy of widespread poaching, musk deer species are classified as endangered (Yang et al., 2003; Aryal et al., 2010; Aryal and Subedi, 2011). In China in the 1950s, as populations crashed and musk deer became rarer, farms began operating to conserve the species and support the need for musk products (Homes, 1999). The industry has grown little since then with current estimates of between 5000 and 6000 captive individuals in more than ten musk deer farms throughout China (Meng et al., 2006, 2011).

The wild musk deer are highly territorial animals (Green, 1986, 1987; Meng et al., 2011) which has posed problems in domestication attempts. Generally, captive farming of wild animals involves establishing an artificial population, in which factors such as age and gender of individuals must be considered. In China, farm management practices, developed during the early stages of musk deer farming, are still applied to those farms currently operating. These management systems are based on perceived social structures and aggression patterns observed in artificially established populations. From current understanding, it is believed little conflict occurs between the sexes; in fact the most intense interactions are those that lead to copulation when enclosed together. An additional perception has been increased domination with age leading to lower ranked individuals being attacked more frequently. Therefore, musk deer with similar fighting abilities and dominance ranks historically have been kept in one enclosure in order to counter antagonism and reach stability (Zhang, 1979; Meng et al., 2006). Despite these predictions being the basis for farming practices and management since the inception of musk deer farming, they remain largely untested. To improve musk deer farming and provide a sustainable source of musk, it is essential that these 'best practice' farming methods are formally studied. Any recommendations on the social structure of artificial populations will aid in reducing captivity stress improving both farm productivity and the welfare of animals (Estevez et al., 2007).

Through observations of a captive musk deer population, this study aimed to determine potential relationships between antagonistic behaviour, age, gender of opponent and overall welfare of captive musk deer.

\section{Material and methods}

\section{Animals and management}

This study was conducted at Xinglongshan Musk Deer Farm (XMDF) in Gansu Province, northwest China $\left(35^{\circ} 38^{\prime} \mathrm{N}, 103^{\circ} 50^{\prime} \mathrm{E}\right)$. Groups of five individuals were housed in outdoor yards $(10 \times 10 \mathrm{~m})$, with unrestricted access to adjoining indoor brick cells $\left(4 \mathrm{~cm}^{2}\right)$. Neighboring enclosures were separated by wire mesh, enabling olfactory and auditory communication between individuals, but prevented physical contact. Enclosure facilities and the daily managing system are detailed in Meng et al. (2003). 
Twenty-five captive alpine musk deer (13 males and 12 females) were observed during non-mating season from July to September 2008. There were two single sex enclosures with five males in each enclosure, three mixed sex enclosures with four females and one male in each enclosure. Individuals were all adults with diversified origins such as being bred in captivity, captured as a fawn or adult in the wild or introduced from another farm. All animals were individually identified by numbered ear tags.

\section{Definition of behavioural patterns and data collection}

Musk deer were observed and conflict interactions were recorded (Altman, 1974). The following antagonistic behaviours were recorded:

Attacking: obvious and agonistic physical contact, initiated by one individual including biting, chasing or attacking with forelegs; threatening: individual with head up and ears erect, displaying canines, vibrating lips, and waggling the rear part of body with actions including approaching, circling and retreating; displacing: one individual approaches another who then retreats.

The conflicts among individuals occurred during peak activity period. Behavioural sampling was conducted from 05:00 to 08:00 and 17:00 to 20:00 (Meng et al., 2002). A single researcher completed all behavioural observations.

\section{Statistical analysis}

Musk deer dominance index (DI) was calculated as: $(1 / \mathrm{N}) \times \sum\left(\mathrm{W}_{\mathrm{i}} / \mathrm{T}_{\mathrm{j}}\right)$ where: $\mathrm{N}=$ total number of opponents; $\mathrm{Wi}=$ number of wins in agonistic interactions with opponent $\mathrm{i}$; $\mathrm{Ti}=$ total number of agonistic interactions with opponent i (Bro-Jørgensen, 2002). Five individuals in each enclosure were categorized as high-rank group (rank =1 2), middle-rank group (rank =3) and low-rank group (rank=4 5). The fight frequency was calculated as: $(\mathrm{A} / \mathrm{B}) \times 100 \%$, where: $\mathrm{A}=$ the number of agonistic interactions initiated or received by object; $\mathrm{B}=$ the total number of agonistic interactions initiated or received by all individuals in one enclosure population or group.

The Spearman correlation test was used to analyse the correlation between age and social hierarchy of male deer, and Friedman test was applied to explore the difference among the agonistic types in conflict receiving by male and female, respectively. If the difference was significant, Wilcoxon test was used to explore the potential difference between agonistic types. Moreover, the influence of gender on the agonistic type was compared by Mann-Whitney test. Statistical analysis was conducted with SPSS11.0 (SPSS Inc., Chicago, Illinois), using two tailed probability, with a significance level of $\mathrm{P}=0.05$.

\section{Results}

\section{Relationship between dominance hierarchy and age of males}

Dominance hierarchy was not significantly correlated with age of captive male musk deer in XMDF (Spearman correlation test, $\mathrm{r}=0.107, \mathrm{P}=0768>0.05$ ). Social rank 
of the older individuals in captive male population was no higher than younger individuals.

\section{Agonistic interaction to male opponent initiated by male musk deer}

There were three agonistic behaviours recorded between males with significant difference among interaction types (Friedman test: $\mathrm{P}=0.001<0.01$ ) (Fig. 1). The threatening behaviour $(56.38 \% \pm 7.28 \%$ ) (mean $\pm \mathrm{SE}$, the same as below) expressed by males was expressed significantly more than attacking $(17.86 \% \pm 5.94 \%)$ $(\mathrm{P}=0.013<0.05)$ and displacing behaviour $(25.78 \% \pm 3.66 \%)(\mathrm{P}=0.011<0.05)$, the latter two agonistic types, however, were not statistically different $(\mathrm{P}=0.373>0.05)$.

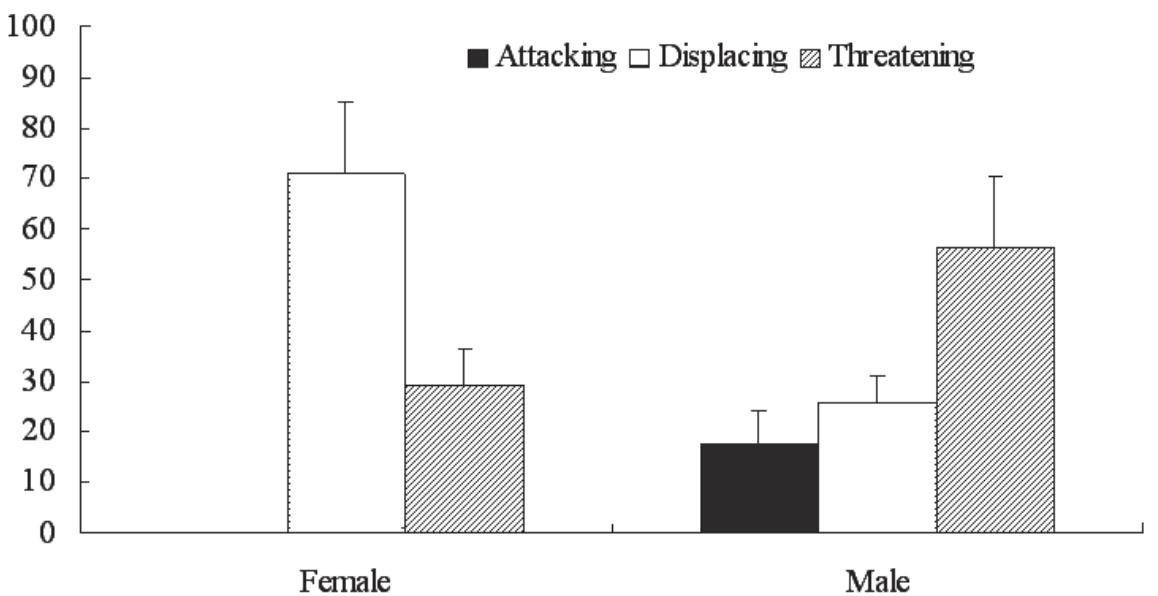

Fig. 1. Agonistic interactions between male and female musk deer in captivity (the line in middle of histogram is SE)

\section{Agonistic interaction to female opponent initiated by male musk deer}

In gender mixed captive musk deer groups, stable social rank patterns appeared with the average dominance rank of male individuals being higher than female's. Moreover, almost no attacking occurred in interactions with female musk deer (Fig. 1), with only displacing $(70.85 \% \pm 4.15 \%)$ and threatening $(29.15 \pm 4.15 \%)$ behaviour recorded and the difference among these agonistic interaction types was not significant (Friedman test: $\mathrm{P}=0.153>0.05$ ).

\section{Relationship between agonistic interaction types}

The difference between the same agonistic type to female and male musk deer was explored and it was found that the total agnostic interactions towards males $(56.38 \pm 7.28 \%)$ were more than those directed towards females $(29.15 \% \pm 4.15 \%)$, although the difference was not significant (Mann-Whitney test, $\mathrm{P}=0.105>0.05$ ). 
Moreover, no attacking occurred in male-female interactions, which was significantly less than male only interactions (17.86 $\pm 5.94 \%)$ (Mann-Whitney test, $\mathrm{P}=0.011<0.01)$.

\section{Discussion}

\section{Relation between age and social rank}

The dominance hierarchy pattern in social animal populations is intricate and influenced by many factors (Bro-Jørgensen, 2002; Barroso et al., 2000) and the complexity of the interactions increase when these animals are in captive populations (Estevez et al., 2007; Andersen et al., 2004). The integrative influence of an individual's physical and behavioural characteristics on its dominance hierarchy is one of the hotspot topics in social hierarchy studies. Syme et al. (1979) demonstrated that age, gender and physical characteristics influenced the social rank of captive animals, in which age is one of the important influencing factors. Generally speaking, the age of an ungulate is related to its social dominance. In fallow deer (Dama dama), Sorraia horses (Equus caballus), African elephants (Loxodonta Africana) and Dama gazelle (Gazella dama), older individuals consistently dominate younger ones (Komers et al., 1997; Heitor et al., 2006; Wittemyer and Getz, 2007; Cassinello and Pieters, 2000). In musk deer, a similar pattern has been found, with individual age positively correlated to the social rank in semi-captive forest musk deer (Moschus berezovskii) (Sheng, 1992; Sheng and Ohtaishi, 1993). However, our results showed no significant correlation between an individual's age and its social rank in male musk deer at XMDF. This difference may have resulted for a number of reasons.

Firstly, captive animals in XMDF have diverse origins, being either born in captivity, captured from the wild as a fawn or as an adult or introduced from other farms. Each animal experiences varying degrees of stress and will adapt to their captive environment differently (Bornet et al., 2000). Musk deer in this study may respond differently to stress resulting from their management treatment along with competition for limited resources such as food and shelter. Such uncontrollable variability could be a reason for not finding the expected significant result between dominance hierarchy and age, a result found previously in similar situations (Komers et al., 1997; Heitor et al., 2006; Wittemyer and Getz, 2007; Cassinello and Pieters, 2000). However, this is not the first study to report such a result. For example, Eccles and Shackleton (1986) found there was no significant correlation between social status and age in female bighorn sheep (Ovis canadensis). Similarly, Kondo and Hurnik (1990) reported that, compared to the age variable, the social experience of a cow (Bos primigenius) and the familiarity with other individuals could influence its bout success and dominance rank. Kim and Zuk (2000) also demonstrated social rank of the domestic chicken (Gallus gallus) is more closely related to early experience, meaning the social rank of individuals with prior social experience is inclined to be higher.

Social hierarchy has also been found to be related to the management system individuals experience (Estevez et al., 2007). In XMDF, the daily husbandry tasks 
include cleaning and adjusting the enclosure, performing veterinary requirements and musk extracting, all of which occur frequently and within close proximity to the animals (Zhang, 1979, 1983). This may impose a significant impact on the social structure and social rank pattern of captive musk deer, and consequently, causing the relationship between age and dominance hierarchy to be more complex at XMDF.

In conclusion, the social rank pattern of captive musk deer under current intensive farming systems depends not only on the individuals' age, but also on other variables such as its origin and the related social experience of the captive animal.

Relationship between aggression type and the gender of aggression receiver

Conflict in population could impose potential physical damage to rivaling individuals, including the fight initiator and aggression receiver (Clutton-Brock et al., 1982). Therefore, animals tend to adopt an optimal fighting strategy through an evolved benefit-cost assessment, that is, an individual, when expressing aggression, does so at the appropriate intensity in respect to the context. Acts of aggression that use less energy and are likely to be less risky in terms of injury, such as displacement or ritual displays, are more desirable than more intensive threatening and hard fighting (Kaufmann, 1983). In this study, although all three agonistic conflict types were initiated by males towards other male opponents, males expressed threatening and displacing more frequently than direct attacks.

For both wild and captive animals, fighting strategy applied during agonistic interactions, and fighting intensity in conflict are related to the social hierarchy of the group as well as the age and gender of the rivaling individuals (Mattiangeli et al., 1999). The above conclusion was supported by our results. Conflict among individuals in animal social population is primarily a function to gain priority access to resources including food and mates (Estevez et al., 2007). In this study, most male musk deer were excluded from females, thus the reward of winning a conflict was only food and individual space, which are not so limited in captivity. Competition among grouped individuals was not as strong as in the wild, therefore, if the fight initiator demonstrates a direct attack with high intensity, the benefit of winning the conflict will be less than the potential damages and the redundant time-energy cost. Accordingly, the captive males tended to express less intensive non-contact interaction such as threatening and displacement.

Moreover, our results showed that there were also conflicts between female and male individuals in XMDF, which differed from previous reports (Zhang, 1979, 1983). In captive musk deer populations, interactions between female and male deer were in the form of social exploration behaviour initiated by males, which in general, was a courting behavioural sequence, causing the female to escape from the approaching male if it was not in oestrus (Meng et al., 2003); consequently, the female was displaced by males.

\section{Recommendations to improve musk deer farming and welfare}

The results of this study have significant implications to successful musk deer farming and the improvement of animal welfare. Firstly, when artificial populations are established in musk deer farms, individuals' social rank and aggression level 
should not be predicted by an individual's age alone, but include such variables as the origin and experience of the deer. Secondly, the management systems employed by farms should be kept as consistent as possible and not be altered more than is needed so as to maintain stable social hierarchy patterns. Routine maintenance and feeding should be carried out at regular intervals to limit unnecessary stress on the animals.

Moreover, as wild musk deer are solitary animals (Green, 1986), if the related farming costs are economically viable, it would be optimal to keep males in solitary enclosures. Even though this study did not observe male musk deer physically attacking females, the displacement and threatening behaviour displayed was enough to result in an intense behavioural response from the female. This additional avoidable stress can cause a variety of issues to females, including the abortion of the foetus. Therefore, a final recommendation would be to separate male musk deer from females for the majority of the year, only bringing them together to mate, and once successful, the female should be removed once again.

\section{References}

A $1 \mathrm{t}$ m a n n J. (1974). Observational study of behavior: sampling methods. Behaviour, 49: 227-267.

A n d e r s e n I.L., Næv d a l E., B a k k e n M., B ø e KE. (2004). Aggression and group size in domesticated pigs, Sus scrofa: when the winner takes it all and the loser is standing small. Anim. Behav., 68 (4): 965-975.

A ry a 1 A., Subedi A. (2011). Conservation and potential habitat of Himalayan musk deer Moschus chrysogaster in the protected areas of Nepal. Int. J. Conserv. Sci., 2 (2): 127-141.

Aryal A., R a ub e n he i m er D., S u be d i S., K a t t el B. (2010). Spatial habitat overlap and habitat preference of Himalayan musk deer Moschus chrysogaster in Sagarmatha (Mt. Everest) National Park, Nepal. Curr. Res. J. Biol. Sci., 2 (3): 217-225.

B a r ro s o F.G., A l a d o s C.L., B o z a J. (2000). Social hierarchy in the domestic goat: effect on food habits and production. Appl. Anim. Behav. Sci., 69: 35-53.

B o r n e t H.L.I., M or g a n C.A., L a w r e n c e A.B., M a n n J. (2000). The effect of group housing on feeding patterns and social behavior of previously individually housed growing pigs. Appl. Anim. Behav. Sci., 70: 127-141.

B ro-Jørgensen J. (2002). Overt female mate competition and preference for central males in a lekking antelope. Proc. Nat. Acad. Sci. U.S.A., 99 (14): 9290-9293.

C a s s in e 11 o J., P i e te r s I. (2000). Multi-male captive groups of endangered dama gazelle: social rank, aggression, and enclosure effects. Zoo Biol., 191 (2): 121-129.

Clutton-B r o ck T.H. (1982). The function of antlers. Behaviour, 78: 108-125.

Eccles T.R., Shacklet on D.M. (1986). Correlates and consequences of social status in female bighorn sheep. Anim. Behav., 34: 1392-1401.

E s t e ve z I., A n d e r s e n I.L., N æ v d a 1 E. (2007). Group size, density and social dynamics in farm animals. Appl. Anim. Behav. Sci., 103: 185-204.

Gr e e n M.J.B. (1986). The distribution, status and conservation of the Himalayan musk deer (Moschus chrysogaster). Biol. Conserv., 35: 347-375.

Gre e n M.J.B. (1987). Scent-marking in the Himalayan musk deer. J. Zool., 1: 721-737.

He it or F., d o Mar O o m M., V i c e n te L. (2006). Social relationships in a herd of Sorraia horses: Part II. Factors affecting affiliative relationships and sexual behaviours. Behav. Process., 73 (3): 231-239.

H o m e s V. (1999). On the scent: Conserving musk deer - the uses of musk and Europe's role in its trade. TRAFFIC Europe, Brussels, Belgium. 
K a u fman n J.H. (1983). On the definition and functions of dominance and territoriality. Biol. Rev., 58: $1-20$.

$\mathrm{K} \mathrm{im} \mathrm{T.,} \mathrm{Zuk} \mathrm{M.} \mathrm{(2000).} \mathrm{The} \mathrm{effects} \mathrm{of} \mathrm{age} \mathrm{and} \mathrm{previous} \mathrm{experience} \mathrm{on} \mathrm{social} \mathrm{rank} \mathrm{in} \mathrm{female} \mathrm{red}$ junglefowl, Gallus gallus spadiceus. Anim. Behav., 60: 239-244.

K o m e r s P.E., P e l a b o n C., S t e n s tro m D. (1997). Age at first reproduction in fallow deer: agespecific versus dominance-specific behaviors. Behav. Ecol., 8: 456-462.

K on d o S., H u rn ik J.F. (1990). Stablization of social hierarchy in dairy cows. Appl. Anim. Behav. Sci., 27: 287-297.

Matti angeli V., Mattiello S., V e rg a M. (1999). The fighting technique of male fallow deer (Dama dama): an analysis of agonistic interactions during the rut. J. Zool., 249, 3: 339-346.

Meng X., Y a ng Q.F.Z., X i a L., W a n g P., J i an g Y., B a i Z., L i G. (2002). Preliminary studies on the activity during summer, autumn and winter season in captive Alpine musk deer. Acta Theriol. Sin., 22: 87-97.

Meng X., Y an g Q., Xi a L., F e n g Z., Ji an g Y., W a n g P. (2003). The temporal estrous patterns of female alpine musk deer in captivity. Appl. Anim. Behav. Sci., 82: 75-85.

Meng X., Z hou C., H u J., Li C., M eng Z., F eng J., Z hou Y., Z hu Y. (2006). The musk deer farming in China. Anim. Sci., 82: 1-6.

M en g X., Z h a o C., H u i C., L u a n X. (2011). Behavioral aspects of captive alpine musk deer during non-mating season: gender differences and monthly patterns. Asian-Aust. J. Anim. Sci., 24 (5): $707-712$.

Parry-Jone s R., W u J.Y. (2001). Musk deer farming as a conservation tool in China. TRAFFIC, East Asia, Hong Kong.

She n g H. (1992). Deer of China (in Chinese with English abstract). East China Normal University Press, Shanghai.

S h e n g H., O h t a i s h i N. (1993). Editors. Deer of China: Biology and Management. Elsevier Science Publishers, Amsterdam, The Netherlands.

S hre s th a M.N. (1998). Animal welfare in the musk deer. Appl. Anim. Behav. Sci., 59: 245-250.

S y m e G.J., S y m e L.A. (1979). Social structure in farm animals. Elsevier, Amsterdam, The Netherlands.

W i t t e m y e r G., G e tz W.M. (2007). Hierarchical dominance structure and social organization in African elephants, Loxodonta Africana. Anim. Behav., 73 (4): 671-681.

Y a ng Q., Meng X., F eng Z., X i a L. (2003). Conservation status and causes of decline of musk deer in China. Biol. Conserv., 109: 333-342.

Z h a n g B. (1979). The farming of musk deer in China (in Chinese). Agriculture Press, Beijing.

$\mathrm{Zh}$ an g B. (1983). Musk deer: their capture, domestication and care according to Chinese experience and methods. Unasylva, 35: 16-24.

Accepted for printing 9 XII 2011

\section{XIUXIANG MENG, ANDREW SIH, HAITAO LI, NICHOLAS CODY}

\section{Ilościowa analiza wzorców agresji w populacji piżmowców (Moschus sifanicus) hodowanych w niewoli}

\section{STRESZCZENIE}

Piżmowiec (Moschus sifanicus) stał się gatunkiem zagrożonym wskutek degradacji i utraty siedlisk oraz wielowiekowego kłusownictwa. W rezultacie wprowadzono hodowlę piżmowców nie tylko dla ich ochrony, ale również jako stałe źródło piżma. Lepsze zrozumienie socjalnej struktury populacji hodowanych w niewoli jest niezbędne zarówno dla skutecznej hodowli, jak i poprawy dobrostanu zwierząt. Przeprowadzone badania rejestrowały agonistyczne interakcje między zwierzętami hodowanymi w niewoli w Gospodarstwie Hodowli Piżmowców Xinglongshan (XMDF) w północno-zachodnich 
Chinach. Analizowano związek między agresywnymi interakcjami, wiekiem i płcią zwierząt oraz zdrowiem oponenta. Z naszych obserwacji wynika, że stabilne hierarchie socjalne rozwinęły się zarówno w grupach samców, jak i w grupach mieszanych. Statystycznie istotnej korelacji nie zaobserwowano jedynie pomiędzy wiekiem zwierząt a ich pozycją w hierarchii społecznej, w wyniku czego stwierdzono, że ponieważ pozycji społecznej nie wyznaczał tylko wiek, uszeregowanie pozycji w hierarchii lepiej tłumaczy połączenie innych czynników, takich jak doświadczenie i pochodzenie. Pomiędzy samcami występowały trzy formy zachowań agresywnych, z których grożenie $(56,38 \% \pm 7,28 \%)$ było istotnie częstsze niż atakowanie $(17,86 \% \pm 5,94 \%)$ i wypieranie $(25,78 \% \pm 3,66 \%)$. Nie stwierdzono atakowania w interakcjach inicjowanych przez samców wobec samic, jednak wypieranie $(70,85 \% \pm 4,15 \%)$ występowało częściej niż grożenie $(29,15 \% \pm 4,15 \%)$. Samce inicjujące konflikty wykazywały więcej zachowań atakujących i grożących wobec innych samców niż samic, jednak różnice nie były istotne statystycznie. Uzyskane wyniki można wprowadzić do praktycznego zarządzania hodowlą piżmowców poprzez: 1) częstą rotację zwierząt w zagrodach, 2) usuwanie samców z zagród samic po skutecznym kryciu, 3) zamykanie samców w zagrodach dla zwierząt jednej płci. Ponadto, poprawa hodowli piżmowców i dobrostanu piżmowców hodowanych w niewoli wymaga ujednolicenia systemów zarządzania dla osiągnięcia stabilnej hierarchii socjalnej populacji hodowanych w niewoli. 